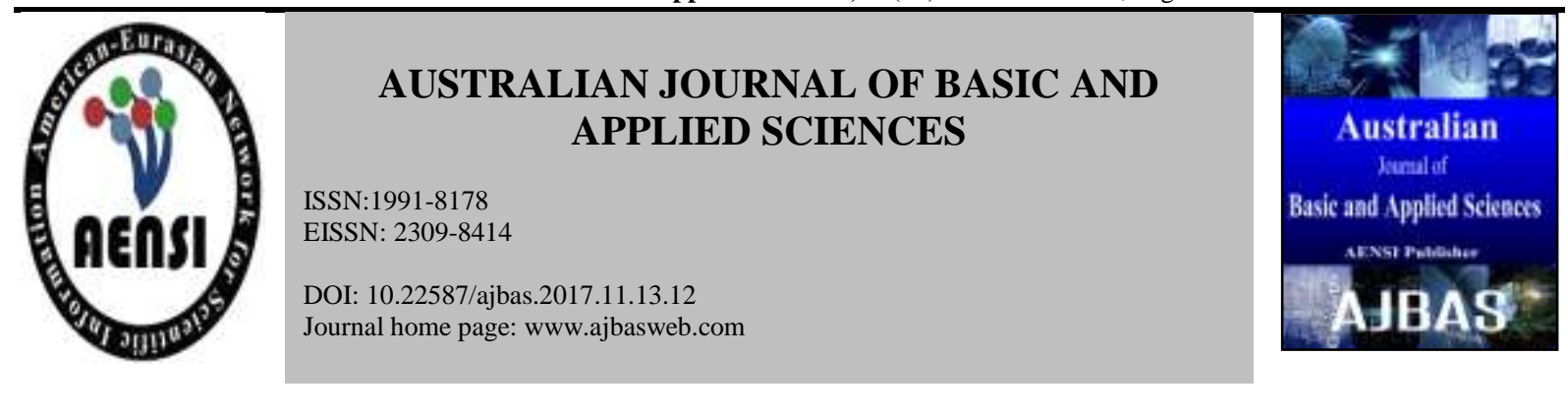

\title{
Biological and Bio- desalination treatments of Mixed Sewage Water
}

\author{
${ }^{1}$ Sayed Ismail, ${ }^{2}$ Eman Marei, ${ }^{3}$ Ahmad Hassan and ${ }^{4}$ Abd Elghany El-Gindy \\ ${ }^{1}$ Sanitary \& Environmental Engineering, Department of Public Works, Faculty of Engineering, Ain Shams University, Cairo, Egypt \\ ${ }^{2}$ Department of Agricultural Microbiology, Faculty of Agriculture, Ain Shams University, Cairo, Egypt. \\ ${ }^{3}$ Department of Genetic Resource, Desert Research Center, Cairo, Egypt. \\ ${ }^{4}$ Department of Agricultural Engineering, Faculty of Agriculture, Ain Shams University, Cairo, Egypt.
}

\section{Address For Correspondence:}

Eman Marei, Department of Agricultural Microbiology, Faculty of Agriculture, Ain Shams University, Cairo, Egypt.

E-mail: wel_memo@yahoo.com

\section{ART I CLE INFO}

\section{Article history:}

Received 19 August 2017

Accepted 1 November 2017

Available online 11 November 2017

Keywords:

Wastewater bio-treatment, Biosorption heavy metals, Biological desalination.

\begin{abstract}
A B S T R A C T
Background: The wastewater is known as a mixture of one or more kinds of different water such as domestic, comprising hospitals, industrial wastewater and agricultural water. Hypersaline environments are important for both surface extension and ecological significance. As all other ecosystems, they are impacted by pollution. However, the available information on the biodegradation of organic pollutants by halophilic microorganisms in such environments are quite limited. Moreover, it is well known that $5 \%$ of industrial effluents are saline and hypersaline. The non-extremophilic microorganisms are unable to efficiently remove the organic pollutants at high salinity. Halophilic microorganisms are different metabolically and are adapted to high salinity. Therefore, these microorganisms are highly recommended to be used in bioremediation of hypersaline environments and treatment of saline effluents. Objective: This study aims to investigate the ability of different compounds in biological treatments of saline wastewater as a new technique for bio-treatment, bio-desalination and bio-removal of different heavy metals in nature circumstances. These compounds were compound I which contains mixture of different bacteria and compound II which contains mixture of different algae. These compounds were prepared under Lab condition. Results: The obtained results indicated that the removal efficiency for bio-treatment, the percentage of removal rate was found to be 79.8 and $83.5 \%$ for BOD, 82.4 and $86.3 \%$ for COD, 52.9 and $57.2 \%$ for ammonia nitrogen and 85.8 and $98.51 \%$ for phosphate. The high bio-removal to different heavy metals were found to reach $84.0 \%$ and $78.50 \%$ for $\mathrm{Al}$ ion, $63.2 \%, 85.50 \%$ for Fe ion, $85.0 \%$ and $89.9 \%$ for $\mathrm{Mn}$ ion and $78.9 \%$ and $84.3 \%$ for $\mathrm{Zn}$ ion. The results indicated that the high removal efficiency and high reduction for TDS were found to reach $39.0 \%$ and $36.0 \%$ after $4 \& 8$ days in case of using compound I and compound II, respectively. The value of power equation $>$ exponential equation for bacteria treated and algae. The correlation coefficient (R2) value of bacteria treated at 0.99, whereas for algae treated at 0.89 for bio-desalination. Conclusion: On the basis of the obtained results it can be concluded that different biological treatments of saline wastewater with compound I and compound II were found to be effective in removal of heavy metals and reduction to TDS at $39.0 \%$ \& $36.0 \%$ after 4 days incubation period at $40^{\circ} \mathrm{C}$ and 8 days incubation at $27^{\circ}-30^{\circ} \mathrm{C}$ for compound I and compound II respectively.
\end{abstract}

\section{INTRODUCTION}

The wastewater is known as a mixture of one or more of: 1- domestic effluent which contains excreta, urine, fecal sludge, kitchen wastewater, bathing wastewater; 2- water from commercial organization and institutions, comprising hospitals; 3- industrial wastewater and; 4- agricultural, horticultural and aquaculture effluent (Corcoran et al., 2010).

Open Access Journal

Published BY AENSI Publication

(C) 2017 AENSI Publisher All rights reserved

This work is licensed under the Creative Commons Attribution International License (CC BY).

http://creativecommons.org/licenses/by/4.0/

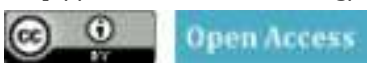

To Cite This Article: Sayed Ismail, Eman Marei, Ahmad Hassan, and Abd Elghany El-Gindy Biological and Bio- desalination treatments of Mixed Sewage Water Aust. J. Basic \& Appl. Sci., 11(13): 108-114, 2017 
Organic and inorganic substances which were released into the environment as a result of domestic, agricultural and industrial water activities lead to organic and inorganic pollution. The normal primary and secondary treatment processes of these wastewaters have been introduced in a growing number of places, in order to eliminate the easily settled materials and to oxidize the organic materials present in wastewater.

Finally, a clear and clean effluent can be obtained and drained into natural water resource. This secondary effluent is loaded with nitrogen and phosphorus in inorganic forms and causes eutrophication and more long term problems because of refractory organics and heavy metals that are discharged. Cultures of microalgae can successfully be used in wastewater treatments, because they provide a tertiary bio-treatment plus production of huge amounts of biomass, which can be used for several purposes (Abdel-Raouf et al., 2012).

Hypersaline environments are important for both surface extension and ecological significance. As all other ecosystems, they are impacted by pollution. However, the available information on the biodegradation of organic pollutants by halophilic microorganisms in such environments are quite limited. Moreover, it is well known that $5 \%$ of industrial effluents are saline and hypersaline. The non-extremophilic microorganisms are unable to efficiently remove the organic pollutants at high salinity. Halophilic microorganisms are different metabolically and are adapted to high salinity. Therefore, these microorganisms are highly recommended to be used in bioremediation of hypersaline environments and treatment of saline effluents. On the basis of the abovementioned information, it can be concluded that both the moderately halophilic bacteria and the extremely halophilic archaea have a broader catabolic versatility and capability than previously thought. A diversity of contaminating compounds is susceptible to be degraded by halotolerant and halophilic bacteria (Borgne et al., 2008).

Also, Elsergany et al. (2014) showed that can be removal efficiency for TDS from 80000 ppm up to 40000 ppm with several runs to get the TDS removal efficiency. The percentage of removal for TDS varied between $13 \& 63 \%$ by algae under the nature circumstances. These variations were due to inlet TDS contents, retention time in the basin and the climatic conditions (sunlight duration \& temperature). The efficient removal for TDS and the results in the highest inlet content was inside the allowed limits for safe discharge to the sea.

Halophiles are microorganisms that can grow well in moderate and high salt concentrations. They are found in all three domains of life: Archaea, Bacteria and Eukarya. Halophilic bacteria grow well over a wide range of salt concentrations (3-15\% NaCl, w/v and higher), unlike the truly halophilic archaea whose growth is restricted to high salinity condition (Litchfield and Gillevet, 2002).

Growth of Scendesmus species in saline water was successfully obtained, since it absorbs salts to be used in its metabolism, Since, Chlorella and Scenedesmus are commonly exhibit extremely wide range of salt tolerance in their habitat, they are known as the most active algae in stabilization ponds (Gimmler, 1981).

Micro-algae have a high capacity for inorganic nutrient uptake and can be used in mass culture in outdoor solar bioreactors. Unicellular green algae such as Chlorella and Scendesmus have been widely used in wastewater treatment because the often colonize the ponds naturally, and they have fast growth rates and high nutrient uptake capabilities. However, one of the major drawbacks of using micro-algae in wastewater treatment is the harvesting of biomass (Laliberte et al., 1997).

The present work focused on the investigation of the possibility of using compound I (mixture of bacteria) and compound II (mixture of algae) in form of free cells as a bio-treatment, biological high desalination and bioremoval of heavy metals from saline wastewater under nature conditions.

\section{MATERIALS AND METHODS}

\section{Source of water:}

High salinity wastewater (sewage water) sample was collected from Ras-surd region, Ras-sudr research station, Egypt after primary treatment. The water sample was taken in sterilized bottles and kept at $4^{\circ} \mathrm{C}$ in a refrigerator for further studies. The sewage water sample was transferred to the Central Lab, Desert Research Center for analysis. characteristics of the collected sewage water sample are presented in table (1).

\section{Microorganisms used for wastewater treatments:}

\section{2. a. Compound I (Mixture of bacteria):}

Bacterial species; halophilic bacteria and yeasts were supplied by Department of Microbiology \& Virology Lab and Cairo MERCIN, Ain Shams University.

Each bacterial species and yeasts were grown on $25 \mathrm{ml}$ of glucose nutrient broth for $48 \mathrm{hr}$ at $35^{\circ} \mathrm{C}$. Whereas, halophilic bacteria were grown on $25 \mathrm{ml}$ of ATCC medium 217 liquid medium for 5 days at $41^{\circ} \mathrm{C}$. The prepared liquid culture $\left(10^{8} \mathrm{cfu} / \mathrm{ml}\right)$ were mixed in a conical flask to form compound $\mathrm{I}$. 


\section{2. b. Compound II (Mixed Algae):}

Different halophilic micro algae were supplied by Department of Microbiology and Virology Lab., Ain Shams University. The algae were grown separately on BG-11 liquid medium at $27^{\circ} \mathrm{C}$ under continuous illumination of fluorescence 5500-6500 lux for 7 days (Roger and Kulasooriya, 1980). The algae liquid cultures were mixed together in a conical flask to form compound II.

Table 1: The chemical characters of the wastewater sample as reported by Central Lab, Desert Research Center.

\begin{tabular}{|c|c|}
\hline Parameters & Unit (mg/L. Sewage water sample) \\
\hline BOD & 176 \\
\hline COD & 339 \\
\hline Ammonia Nitrogen & 142 \\
\hline Phosphate & 90.15 \\
\hline Turbidity (Ntu) & 123 \\
\hline $\operatorname{TDS}(\%)$ & 95.0 \\
\hline TDS (ppm) & 21632 \\
\hline $\mathrm{pH}$ & 7.1 \\
\hline $\mathrm{Ca}$ & 528.2 \\
\hline $\mathrm{Mg}$ & 280.1 \\
\hline $\mathrm{Na}$ & 1200 \\
\hline K & 120 \\
\hline $\mathrm{SO}_{4}$ & 263.14 \\
\hline $\mathrm{Cl}$ & 1724.11 \\
\hline $\mathrm{HCO}_{3}$ & 250.90 \\
\hline $\mathrm{Al}$ & 25.65 \\
\hline B & 0.66 \\
\hline $\mathrm{Cd}$ & 0.06 \\
\hline $\mathrm{Co}$ & 0.03 \\
\hline $\mathrm{Cr}$ & 0.60 \\
\hline $\mathrm{Cu}$ & 0.02 \\
\hline $\mathrm{Fe}$ & 60.86 \\
\hline Mn & 4.14 \\
\hline Mo & 0.001 \\
\hline $\mathrm{Ni}$ & 0.09 \\
\hline $\mathrm{Pb}$ & 0.03 \\
\hline V & 0.24 \\
\hline $\mathrm{Zn}$ & 1.19 \\
\hline
\end{tabular}

\section{Experimental Design and Treatments:}

\section{3.a. Compound I treatment:}

Twelve conical flasks $(500 \mathrm{ml})$ were prepared each contained $400 \mathrm{ml}$ of sewage water. Fifty ml of compound I were added to each flask. The three flasks were incubated with shaking at $40^{\circ} \mathrm{C}$. The contents of one flask $(450 \mathrm{ml})$ were taken after $48 \mathrm{hrs}$ and contents of another flask were collected after $96 \mathrm{hrs}$., whereas, the contents of the third one was collected after $192 \mathrm{hrs}$. The collected samples were centrifuged at $6000 \mathrm{rpm}$ for $15 \mathrm{~min}$ to remove the bacterial cells and the supernatants were subjected to analysis.

\section{3.b. Compound II treatment:}

Twelve $500 \mathrm{ml}$ flasks each contained $400 \mathrm{ml}$ of sewage water were prepared. Fifty $\mathrm{ml}\left(10^{8} \mathrm{cfu} / \mathrm{ml}\right)$ of compound II (Mixed algae) were added to each flask. Flasks were incubated with shaking at $27^{\circ}-30^{\circ} \mathrm{C}$ for 12 days. The contents of one flask $(450 \mathrm{ml})$ were taken after 4 days and contents of another flask were collected after 8 days, whereas, the contents of the third one were collected after 12 days. The collected samples were centrifuged at $6000 \mathrm{rpm}$ for $15 \mathrm{~min}$ to remove the algae cells and the supernatants were subjected to analysis. The supernatants were kept for biochemical analysis at the Central Lab, Desert Research Center.

\section{Adsorption equations:}

Adsorption from aqueous solutions at equilibrium is usually correlated by power equation and exponential equation. The power equation calculated following equation (1):

$q=K C e q^{1 / n}$

In this model, $\mathrm{K}(1 \mathrm{~g}-1)$ and $1 / \mathrm{n}$ are the constants to be determined from the data. A value of $1 / \mathrm{n}$ indicates of rather strong bond between the adsorbate and adsorbent. Exponential equation (2):

$q e=a \cdot e^{b \cdot C e}$

where $q$ e is the amount adsorbed at equilibrium $(\mathrm{mg} / \mathrm{g})$ and $C \mathrm{e}$ is the equilibrium concentration of metal ions in solution $(\mathrm{mg} / \mathrm{L})$ and $b$ is a constant related to the energy of adsorption. The values of $R 2$ are regarded as a measure of the goodness-of-fit of experimental data on these models. 


\section{RESULTS AND DISCUSSION}

\section{Bio-treatment by Compound I \& Compound II of saline wastewater:}

In this study different compounds were used as biological treatments of saline wastewater. The results showed that water contained organic, inorganic matter, high salt concentration and different concentrations of heavy metals.

Reduction of COD, BOD, ammonia nitrogen, phosphate and almonium, iron, manganese and zinc in wastewater were recorded in samples treated with compound I \& II, respectively after different incubation periods at $41^{\circ} \& 27^{\circ}-30^{\circ} \mathrm{C}$. Data presented in table $(2-\mathrm{a} \& \mathrm{~b})$ and figure $(1-\mathrm{a} \& \mathrm{~b})$ indicate that the highest removal percents of COD, BOD, ammonia nitrogen, phosphate and almonium, iron, manganese and zinc were achieved after $4 \& 8$ days. The $\mathrm{pH}$ value was found to be 7.1 to 8.1 during the experiment recorded as compared to untreated ones which was found to be $\mathrm{pH}$ 7.1. These results are in agreement with those found by (Kargi and Dinner, 2000; Awasthi and Rai, 2004; Borgne et al., 2008; Abou-Elela et al., 2010; Krishnan and Neera, 2013).

With increasing the incubation period, the removal efficiency increased in various characteristics of wastewater sample. After incubation for four \& eight days the maximum removal of COD, BOD, Ammonia nitrogen, phosphate and different heavy metals were achieved. Percentage removal rate was found to be $79.8 \%$ \& $83.5 \%$ (BOD) and $82.4 \% \& 86.3 \%$ (COD), ammonia nitrogen $52.9 \%$ \& $57.2 \%$, phosphate $85.8 \%$ \& 98.51 $\%$, Al 84.0\% \& 78.50\%, Fe 63.2\% \& 85.50\%, Mn 85.0\% \& 89.9\% and Zn 78.9\% \& 84.3\% ions by compound I and compound II , respectively. Sorption and removal of heavy metals by algal bio-sorbents largely depend on the initial concentrations of metals in the solution. Metal sorption initially increases with increasing metal concentration in the solution, and then becomes saturated after a certain concentration of metal (Kant and Gaur, 2001). This may be due to the increase in the number of ions competing for the available binding sites in the biomass and also due to the lack of binding sites for the complication of these ions at higher concentration levels. At lower concentrations, all metal ions present in the solution would interact with the binding sites and thus facilitate maximum adsorption. At higher concentrations, more ions are left unabsorbed in solution due to saturation of binding sites (Ahalya et al., 2005).

Due to using compound I \& II to reduction in salinity and removal percentages of high TDS and turbidity were found to be of wastewater was recorded as compared to untreated sample (control). The removal percentages of TDS at $39.0 \% \& 36.0 \%$ and Turbidity at $49.46(\mathrm{Ntu}) \quad \& \quad 37.01(\mathrm{Ntu})$ after 4 \& 8 days Incubation period at $40^{\circ} \mathrm{C} \& 27^{\circ}-30^{\circ} \mathrm{C}$ by compound I and compound II, respectively. Data presented in table $(2-a \& b)$ and figure $(2-a \& b)$. These results are in agreement with those found by (Kargi and Dinner, 2000; Elsergany et al., 2014; El-Nadi et al., 2014).

Table 2: Removal Percentages (\%) of different bio-treatments after different incubation periods.

\begin{tabular}{|c|c|c|c|c|c|c|}
\hline \multirow[t]{2}{*}{ Parameters } & \multicolumn{3}{|c|}{$\begin{array}{l}\text { Compound I (Mixed Bacteria) } \\
\text { Incubation period (day) }\end{array}$} & \multicolumn{3}{|c|}{$\begin{array}{l}\text { Compound II (Mixed Algae) } \\
\text { Incubation period (day) }\end{array}$} \\
\hline & 2 & 4 & 6 & 4 & 8 & 12 \\
\hline BOD & 49.0 & 79.8 & 69.9 & 59.9 & 83.5 & 72.1 \\
\hline COD & 58.2 & 82.4 & 78.1 & 67.5 & 86.3 & 17.8 \\
\hline Ammonia- nitrogen & 50.7 & 52.9 & 30.5 & 43.6 & 57.2 & 39.2 \\
\hline Phosphate & 55.03 & 85.8 & 51.9 & 59.01 & 98.51 & 98.51 \\
\hline Turbidity (Ntu) & 23.2 & 49.46 & 28.97 & 19.83 & 37.01 & 33.6 \\
\hline TDS (\%) & 95.0 & 36.0 & 43.0 & 83.0 & 39.0 & 41.0 \\
\hline $\mathrm{pH}$ & 7.1 & 7.1 & 7.1 & 7.5 & 7.8 & 8.1 \\
\hline $\mathrm{Al}$ & 81.0 & 84.0 & 75.0 & 60.70 & 78.50 & 72.10 \\
\hline $\mathrm{Fe}$ & 42.0 & 63.2 & 55.4 & 67.95 & 85.50 & 70.9 \\
\hline $\mathrm{Mn}$ & 57.0 & 85.0 & 51.4 & 66.4 & 89.9 & 71.1 \\
\hline $\mathrm{Zn}$ & 40.33 & 78.9 & 63.2 & 50.7 & 84.3 & 78.9 \\
\hline
\end{tabular}

\section{Adsorption equations:}

In this study the value of $\mathrm{NaCl}$ reduction by power equation at $((1 / \mathrm{n}=5.78$ and $4.83, \mathrm{Kf}(\mathrm{mg} / \mathrm{g})=0.0092$ and 0.143 and the correlation coefficient $(\mathrm{R} 2)$ value $=0.99$ and 0.89$)$ for bacteria and algae treated respectively, whereas the value of $\mathrm{NaCl}$ reduction by exponential equation at $(\mathrm{B}=0.278$ and $0.247, \mathrm{Kt}(\mathrm{L} / \mathrm{mg})=1161$ and 1984 and the correlation coefficient $(\mathrm{R} 2)$ value $=0.97$ and 0.85 ) for bacteria and algae treated respectively, so power equation > exponential equation for bacteria treated and algae, data shown in table (3).

According to (Kadirvelu and Namasivayam, 2000; Krishna and Swamy, 2012), reported that, the n values between 1 and 10 represent beneficial adsorption. The value of $n$, which is related to the distribution of bonded ions on the sorbent surface, was found to be greater than unity indicating that adsorption is favorable. Tien (2002) found that the magnitude of $\mathrm{K}$ and $\mathrm{n}$ showed easy uptake of surface area and dry weight of algal cells. It was found to be the main factor influencing metal sorption and indicates favorable adsorption. Biosorption using biomass derived from fresh water, algae, marine seaweeds and fungi have recently attracted growing interest of researchers. Many potential binding sites occur in algal cell walls and alginate matrices (Saitoh et al., 2001; Tam et al., 1998). 


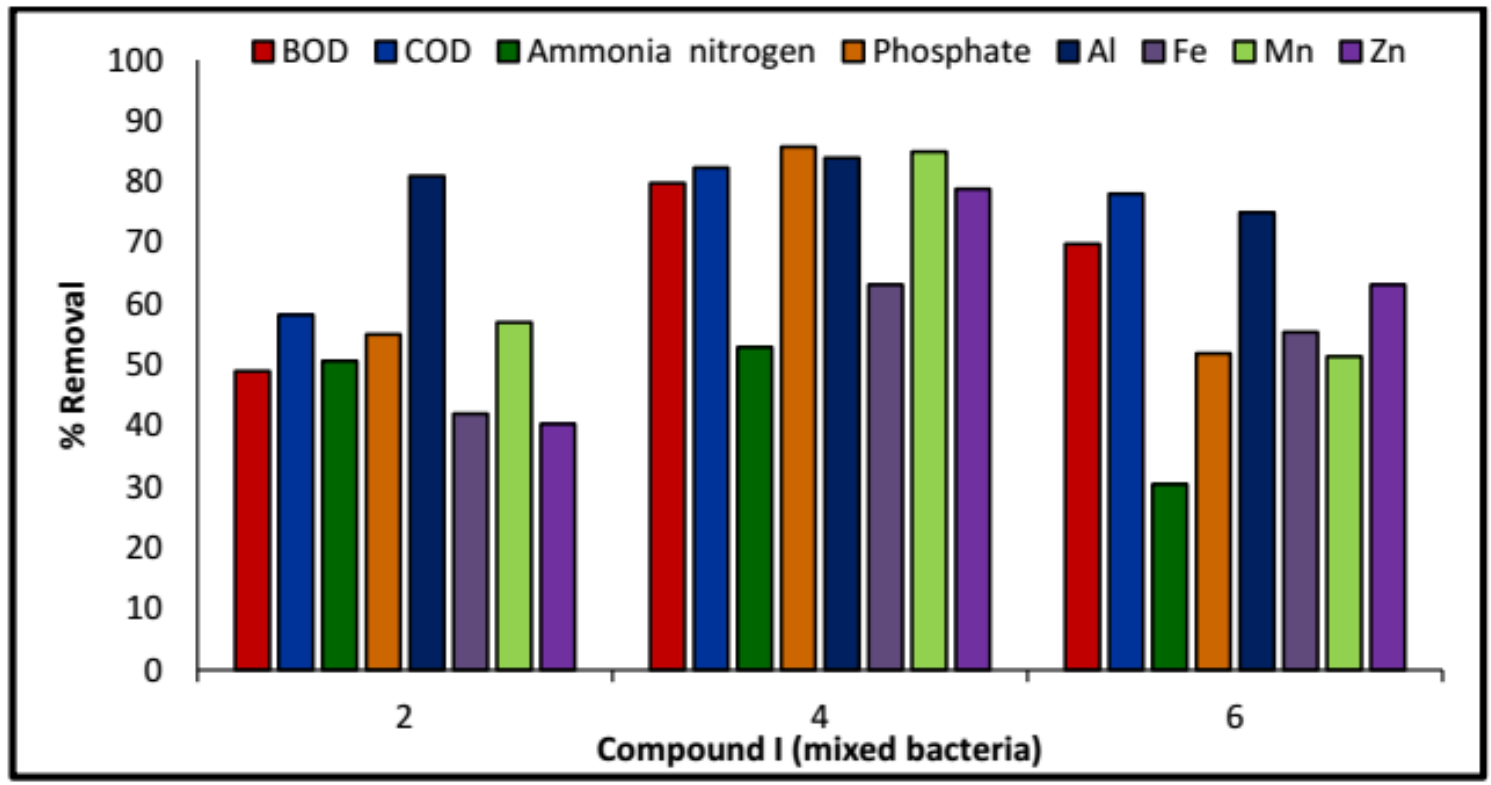

A

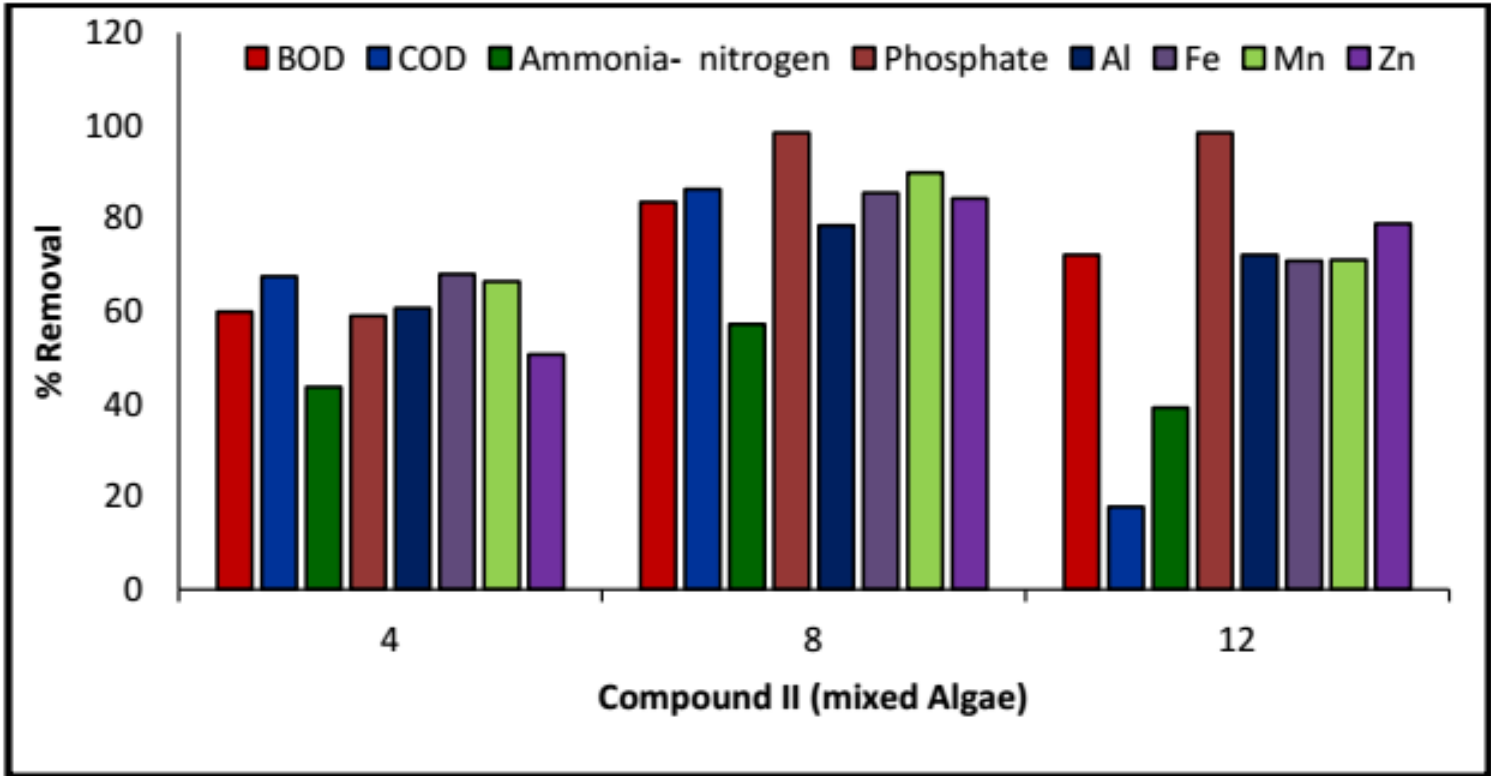

B

Fig. (1-A): Removal percentage at different incubation periods with Compound I (mixed bacteria \& yeast). (1-B): Removal percentage at different incubation periods with Compound II (mixed algae). 


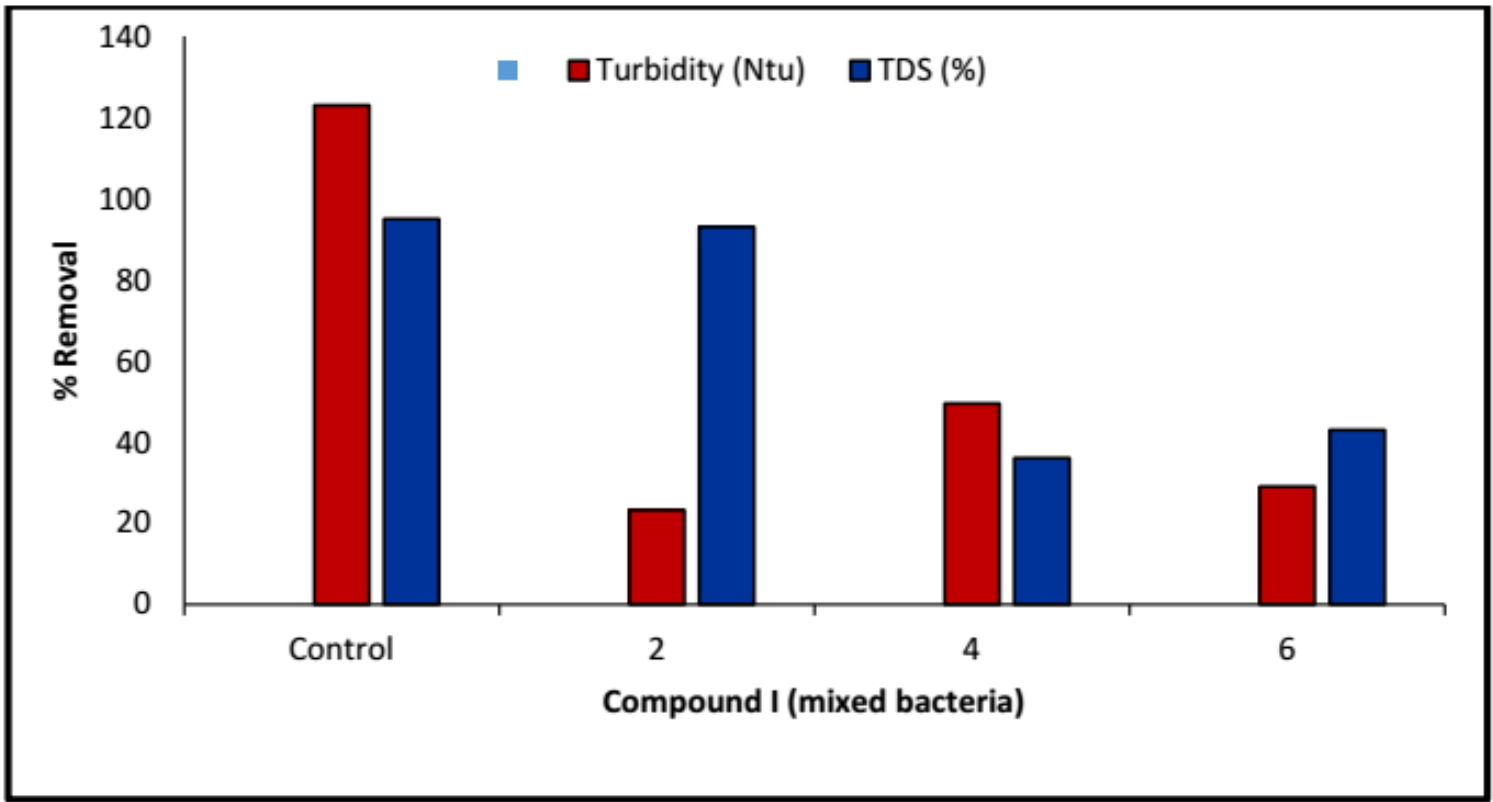

A

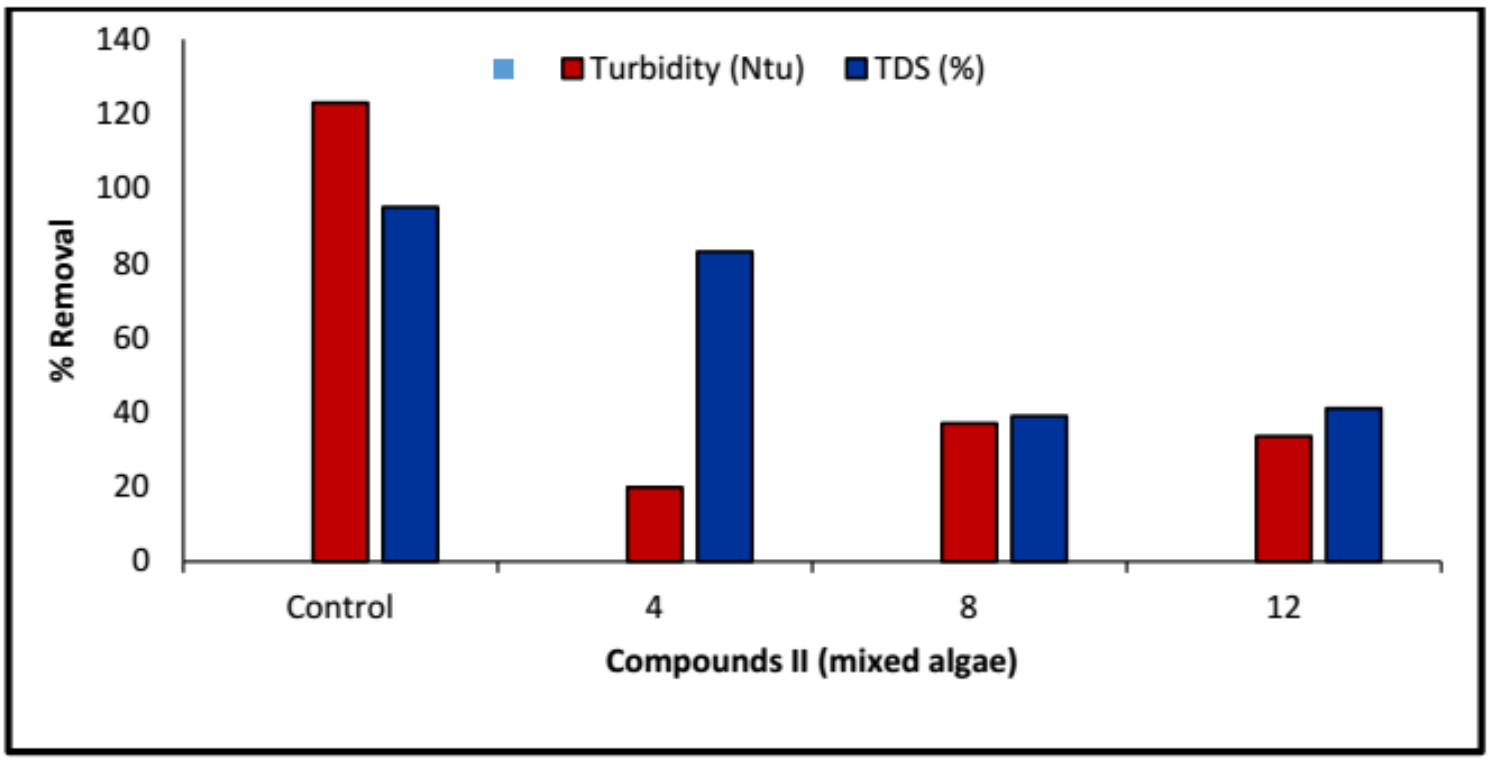

B

Fig. (2-A): Percentage reduction of salinity and turbidity by different incubation periods with compound I (mixed bacteria \& yeast).

(2-B): Percentage (\%) reduction of salinity and turbidity by different incubation periodswith compound II (mixed algae).

Table 3: Estimated different models and their constant values of different treatments for bio-desalination

\begin{tabular}{|c|c|c|c|c|c|c|}
\hline \multirow{3}{*}{ Biosorbant } & \multicolumn{3}{|c|}{ Power equation } & \multicolumn{3}{|c|}{ Exponential equation } \\
\hline & \multicolumn{3}{|c|}{ Days } & \multicolumn{3}{|c|}{ Days } \\
\hline & $\mathrm{R}^{2}$ & $\mathrm{~K}$ & $1 / \mathrm{n}$ & $\mathrm{R}^{2}$ & $\mathrm{~K}$ & $\mathrm{~B}$ \\
\hline Bacteria & 0.99 & 0.0092 & 5.78 & 0.97 & 1161 & 0.278 \\
\hline Algae & 0.89 & 0.143 & 4.831 & 0.85 & 1984 & 0.247 \\
\hline
\end{tabular}

\section{Conclusion:}

On the basis of the obtained results it can be concluded that different biological treatments of saline wastewater with compound I and compound II were found to be effective in removal of heavy metals and reduction of $82.4 \% \& 86.3 \%$, COD , 79.8\% \& 83.5\%, BOD, ammonia nitrogen $52.9 \%$ \& $57.2 \%$ phosphate $85.8 \%$ \& $98.51 \%, \mathrm{Al} 84.0 \%$ \& $78.50 \%, \mathrm{Fe} 63.2 \%$ \& $85.50 \%, \mathrm{Mn} 85.0 \%$ \& $89.9 \%$ and $\mathrm{Zn} 78.9 \%$ \& $84.3 \%$ ions, TDS at $39.0 \% \& 36.0 \%$ and Turbidity at $49.46 \& 37.01(\mathrm{Ntu})$ after 4 days Incubation period at $40^{\circ} \mathrm{C}$ and 8 days incubation at $27^{\circ}-30^{\circ} \mathrm{C}$ for compound I and compound II respectively. Also, the value of $\mathrm{NaCl}$ reduction by power equation at $((1 / \mathrm{n}=5.78$ and $4.83, \mathrm{Kf}(\mathrm{mg} / \mathrm{g})=0.0092$ and 0.143 and the correlation 
coefficient $(\mathrm{R} 2)$ value $=0.99$ and 0.89$)$ for bacteria and algae treated respectively, whereas the value of $\mathrm{NaCl}$ reduction by exponential equation at $(\mathrm{B}=0.278$ and $0.247, \mathrm{Kt}(\mathrm{L} / \mathrm{mg})=1161$ and 1984 and the correlation coefficient $(\mathrm{R} 2)$ value $=0.97$ and 0.85 ) for bacteria and algae treated respectively, so power equation > exponential equation for bacteria treated and algae.

Therefore, the use of compound I and compound II is highly recommended for bio treatment and bio desalination of wastewater high salinity. The importance of this research is due to the use of alternative and safe methods in treating salinity wastewater and reuse in re-irrigation of some types of trees and non-paper plants, which in turn helps reduce the tap water used.

\section{ACKNOWLEDGMENT}

Thanks to Prof. Dr. Adel. M. Hammad, Prof of Agricultural microbiology, Faculty of Agriculture, Minia University for his critical revision of the manuscript.

\section{REFERENCES}

Abdel Raouf, N., A.A. AlHomaidan and I.B.M. Ibraheemb, 2012. Microalgae and wastewater treatment. Saudi Journal of Biological Sci., 19(3): 257-275.

AbouElela, S.I., M.M. Kamel and M.E. Fawzy, 2010. Biological treatment of saline wastewater using a salt tolerant microorganism. Des., 250(1): 1-5.

Ahalya, N., R.D. Kanamadi and T.V. Ramachandra, 2005. Biosorption of chromium(VI) from aqueous solutions by the husk of Bengal gram (Cicer arientinum). Electr. J. Biotechnol., 8: 258-264.

Awasthi, M and L.C. Rai, 2004. Adsorption of nickel, zinc and cadmium by immobilized green algae and cyanobacteria: A comparative study. Annals Microbiol, 54: 257-267.

Borgne, S.L., D. Paniagua and R. Vazquez-Duhalt, 2008. Biodegradation of Organic Pollutants by Halophilic Bacteria and Archaea. J. Mol. Microbiol. Biotechnol., 15(2-3): 74-92 (DOI: 10.1159/000121323).

Corcoran, E., C. Nellemann, E. Baker, R. Bos, D. Osborn and H. Savelli (eds), 2010. Sick Water? The central role of wastewater management in sustainable development. A rapid Response Assessment. United Nations Environment Programme, UN-HABITAT, GRID-Arendal. www.grida.no ISBN: 978-82-7701-075-5, Report compiled by GRID-Arendal has been an interagency collaboration led by UNEP and UN-HABITAT in partnership with members of UN Water.

El Nadi, M.H.A., F.A.G.H. El Sergany and O.M. El Hosseiny, 2014. Desalination using algae ponds under nature Egyptian conditions. Journal of Water Resources and Ocean Sci., 3(6): 69-73.

El Sergany, F.A.R., M. El Fadly and M.H.A. El Nadi, 2014. Brine Desalination by Using Algae Ponds Under Nature Conditions. American Journal of Environmental Eng, 4(4): 75-79.

Gimmler, H., C. Wiedemann and E.M. Möller, 1981. The Metabolic Response of the Halotolerant Green Alga Dunalella parva to Hypertonic Shocks. Ber. Deutsch. Bot. Ges. Bd., 94(1): 613-634.

Kadirvelu, K and C. Namasivayam, 2000. Agricultural by-products as metal adsorbents: Sorption of lead (II) from aqueous solutions onto coir-pith carbon. Environ. Technol., 21: 1091-1097.

Kant, M.S and J.P. Gaur, 2001. Removal of Ni and $\mathrm{Cu}$ from single and binary metal solutions by free and immobilized Chlorella vulgaris. European J. Protist, 37: 261-271.

Kargi, F and A.R. Dinner, 2000. Use of halophilic bacteria in biological treatment of saline astewater by fedbatch operation. Water Environment Res.,72(2): 170-174.

Krishnan, A and A. L. Neera, 2013. Waste water treatment by algae. International Journal of Innovative Research in Science, Engineering and Tech, 2(1): 286- 293.

Krishna, R.H and A.V.V.S. Swamy, 2012. Physico-chemical key parameters, Langmuir and Freundlich isotherm and Lagergren rate constant studies on the removal of divalent nickel from the aqueous solutions onto powder of calcined brick. International Journal of Engineering Research andDevelopment, 4(1): 29-38.

Laliberte, G., P. Lessard, J. dela-Noue and S. Sylvestre, 1997. Effect of phosphorus addition on nutrient removal from wastewater with the cyanobacterium Phormidium bohneri. Bioresource Technol, 59:227-233.

Litchfield, C.D and P.M, Gillevet., 2002. Microbial diversity and complexity in hypersaline environments: a preliminary assessment. Ind. J. Microbiol. Biotechnol., 28(1): 48-55.

Roger, P.A and S.A. Kulasooriya, 1980. Inter. Rice Res.Institute, IRRI Pub. Manila, Phili, pp: 1-117.

Saitoh, T., N. Nakagaki, Y. Uchida, M. Hiraide and C. Matsubara, 2001. Spectrophotometric determination of some functional groups on Chlorella for the evaluation of their contribution to metal uptake. Anal. Sci., 6: 793-795.

Tam, N.F.Y., Y.S. Wong and C.G. Simpson, 1998. Repeated removal of copper by alginate beads and the enhancement by micro algae. Biotechnol. Tech, 12: 187-190.

Tien, C.J., 2002. Biosorption of metal ions by freshwater algae with different surface characteristics . Process Biochemis, 38: 605-615. 